\title{
THE ROLE OF BUSINESS INNOVATION IN IMPROVING THE PRODUCT COMPETITIVENESS OF FOOD MICRO INDUSTRY IN SOUTHEAST SULAWESI, INDONESIA
}

\author{
Palilati Alida*, Samdin, Sukotjo Endro, Saleh Salma, Kamaluddin Murdjani \\ Faculty of Economics and Business, University of Halu Oleo, Kendari, Indonesia \\ *E-mail: alyda palitati@yahoo.com
}

\begin{abstract}
This research was conducted to investigate and describe the role of business innovations implemented by food micro industry players to obtain better product competitiveness. This research was conducted using a quantitative research approach and was carried out in food micro industry in Southeast Sulawesi. There were 174 samples that were purposively selected including business owner and management team listed in the Department of Industry and Trade of the Southeast Sulawesi. Path analysis using SmartPLS was performed to analyze the research data. The results of this research showed that business innovation gave significant and positive contribution up to $60 \%$ to the enhancement of product competitiveness. The most appropriate business innovation to be applied in improving the food micro industry in Southeast Sulawesi was marketing innovation. Business innovation for marketing sector was necessary in improving and marketing unique products that could be done by adding more attractive product variants that to meet the market preference, demand, and necessities.
\end{abstract}

\section{KEY WORDS}

Business, innovation, competitiveness, marketing innovation.

Food industry (culinary) is reasonably categorized as a part of creative industries. In Indonesia, MSMEs plays a strategic role in increasing the economic growth which number keeps increasing every year. This development expands employment opportunities; provides broader economic services to the community; promotes equitable development and income; encourages economic growth and enhances the national stability. Small, micro and medium enterprises are one of the main pillars of the Indonesian economy that should be prioritized, supported, protected, and developed (Dhewanto et.al, 2015: 33).

The increase in the number of MSMEs leads to increasingly fierce business competition, demanding entrepreneurs to think creatively and innovatively for better performance and competitiveness in the dynamic market that keeps changing due to technological advances. For small companies, innovation is the driver to compete with their competitors (Hadiyati, 2012). The intense competition requires every company to understand what and how to manage various resources available. The ability to create competitive advantage is an important key to win the competition. Narver and Slater (1990, p.21) stated that competitive advantage can be achieved if a company is able to provide added-value to customers in better ways than the competitors. Competitive advantage can be enhanced through various company activities including the design, production, marketing, delivery and support of the products. Each of these activities must be directed to support the relative cost of the company and to create a basis for market differentiation.

At present, micro food industry in Southeast Sulawesi in general experiences various problems including: limited markets, low demand, inadequate product development, improper use of raw materials and weak product innovation in terms of production process, bookkeeping administration and marketing.

To be able to compete in a target market, a business must be able to overcome various challenges. A company must be able to anticipate changes and customer expectations for the products. A company is not only required to seek value positions that satisfy its target 
customers, but a company should also provide better services than other competitors (Slater \& Narver, 2000: 65). It is obvious that the ability to make innovation is crucial in a business.

\section{LITERATURE REVIEW}

Porter (2008) stated that competitive advantage illustrates the way a company choose and implement certain strategy to achieve and maintain competitive advantage. Competitive advantage is the core of a company's performance within a competitive market. David Xiaosong et al. (2011) stated that company's competitive advantage creates better or unique value. The best way to create this value is by reducing the costs or making product differentiations from other companies. Lowering the cost and product differentiation are the basic strategy for companies that expect to give added-value and gain competitive advantage.

Competitive advantage is a company's ability to create and maintain superiority over its competitors in a tight market competition. Indrajid and Djokopranoto (2005). Gimenez and Ventura, 2005 mentioned that competitive advantage is the key to achieving business success that is then defined as the ability of the industry to have: flexibility, innovation, quality and cost reductions.

Day \& Wensley (1988) explained that competitive advantage has at least two different yet interconnected meanings. First, competitive advantage focuses on excellence in skills or resources (owned resources or inputs) consisting of expertise and superiority of the raw materials. Second, competitive advantage in terms of performance indicators (input work results), namely superior position consists of relative cost advantages and value advantages for customers. According to Song \& Parry (1997) there are three benchmarks that show the competitive advantage: product uniqueness that can distinguish it from competitors' products or general products in the market, product quality, and competitive price which refers to company's ability to produce cost-efficient products.

Reniati $(2013 ; 56)$ sees competitive advantage in the perspective of small businesses is defined as the position of a company against its competitors seen from: product uniqueness strategies; product / service variations; product price / value; business reputation; and customer experience. Product Uniqueness refers to the company's ability to produce unique and different products for consumers to choose. Unique products attract more consumers. Variation of products / services can be done by providing variety of products for consumers. Price / value of the product should be concerned as it reflects the type and quality of the product. Business reputation is also important because companies with good reputation obtain positive impression from consumers. Positive impression is a valuable treasure for a company that should be maintained. Good impression and experience obtained by customers lead to strong consumer satisfaction and brand loyalty.

In running an enterprise, it is necessary to focus on long-term goals and the major goal to earn high profitability. Achieving the long-term goals requires a business management to maintain profitable customer relationships in the long run that can be maintained by enhancing customer satisfaction. Furthermore, customer satisfaction can be improved by providing better quality, service, innovation, product uniqueness, and more competitive prices from other competitors. To win the competition, a company must continuously find and apply added-values and implement proper business strategies and investments (Day \& Wensley, 1988).

Competitive advantage comes from innovative activities carried out by companies in designing, producing, marketing, delivering and supporting their products.

Sustainable business innovation relates to the application of new ideas or processes as a mechanism to adapt to dynamic environment those results in the ability to produce better products and services than other competitors. In order to achieve it, company management is required to create new thoughts, new ideas and offer innovative products or services as well as service improvements that satisfy customers.

Schumpeter (1934) said that innovation is about creating and implementing some aspects to form a good combination. Innovation adds more value to products, services, work 
processes, marketing, delivery systems, and policies for companies, stakeholders and the public as well (in de Jong \& Den Hartog, 2003).

According to Hurley and Hult (1998), innovation is a corporate mechanism to adapt in a dynamic environment. To that end, companies are required to create new thoughts, new ideas and offer innovative products or services to satisfy customers.

Zimmerer and Scarborough (2005) also believed that innovation is the ability to apply creative solutions to address problems and opportunities to improve one's' welfare. Entrepreneurs are innovators beyond inventors who should not stop at the process of creation or discovery of ideas, but they need to realize those ideas into real innovation.

Within the SMSE perspective, business innovation is defined as the implementation of creative ideas in products, processes and marketing to generate higher profits for a company. Eisenbeis and Boerner (2013) found out that transformational leadership has a positive effect on the creativity of employees while the dependencies of employees on their managers results in opposite.

The development of creativity in the workplace is important because creativity is a mandatory stage that precedes innovation; creative ideas are used for innovation. Von Stamm (2008) described it in the following words: "If implementation is putting an idea into practice, creativity is coming up with the idea in the first place. Creativity is an essential part of innovation, is the point of departure". Thus, innovation should start with creativity and it is further developed with respect to the product, the business model, the organizational processes, the applied technology, or the market.

Business innovation as a tool of innovation according to the OSLO manual (2006) deals with the implementation of new ideas to produce significantly better products (goods, or services); it also deals with the implementation of new marketing method or organizational method in business practices, workplaces, organizations or outgoing relationships. Furthermore, there are 4 types of OSLO innovations, namely: product innovation; process innovation; marketing innovation; and organizational innovation. Through innovation, entrepreneurs utilize new product resources and manage existing resources by increasing the potentials of the resources to create new things. Product innovation as explained by Reguia (2014) is the development of a new product or business by making changes in the current product design or using new techniques. Process innovation (process innovation) is the implementation of a totally new delivery system. This innovation should reduce the production costs while satisfy the customer at the same time (Hasan, Shaukat, Nawaz \& Nas, 2013; 246). Marketing innovation is interpreted as the implementation of a new marketing method involving specific changes in this production design, packaging or product placement. Whereas, organizational innovation refers to the implementation of a new organizational method in a firm's business practices, workplace, organization or external relations. There are three elements that should be fulfilled in the process of innovation (Sundho, 2001). The first element is the availability of resources that can be used to make innovation. The resources include physical resources, knowledge, abilities and adequate competencies of employees and managers. Second, dynamic capabilities including the ability to organize an innovation process when needed. The last one is the ability to utilize the existing resources and capabilities to create new products / services at the right time.

According to Scarborough \& Coenwall, (2016: 57), innovation is the ability to apply creative solutions to solve problems and opportunities to improve or to enrich human life.

Najib \& Kiminami (2011) in their research found innovation positively correlated with business performance in terms of relative profitability, market share, and growth. Hence, innovation and business performance of MSMEs are interconnected and important factors for the sustainability of the MSMEs. Strong innovations including process innovation and product innovation will increase the company's ability to create quality products. (Hartini, 2012).

\section{METHODS OF RESEARCH}

This quantitative research took place in Kendari, Kolaka, Bau-Bau and Bombana. This research involved business owners of 25 micro food industry. Surveys were conducted 
to 174 purposively-selected MSME businessmen registered in the Department of Industry and Trade of Southeast Sulawesi Province.

Research data were collected through surveys done using close-ended questionnaires, interviews and observation. The data collection instrument used in this research was in the form of a set of questionnaires using Likert-scale.

The data obtained in this research were quantitative data which were then underwent path analysis using SmartPLS software.

\section{RESULTS AND DISCUSSION}

The model used in this research connected Business Innovation with Competitive Advantage. Business Innovation was reflected by 4 (four) indicators, namely: Product Innovation (X1.1); Process Innovation (Xi.2); Marketing Innovation (X1.3); and Organizational Innovation. While competitive advantage was reflected by: Product uniqueness (Y1.1); Product variations (Y1.2); Value / Price of the product (Y1.3); Reputation (Y1.4); and Customer Experience (Y1.5).

To measure the validity and reliability of each latent variable, the SmartPLS program was employed. The individual reflexive measure of each indicator variable was considered valid if the loading score $\geq 0.5$. If there the score was under requirement, indicator was then excluded as it was considered invalid or not good enough to measure latent variables appropriately. The test was conducted based on the scores between the reflective indicators with the latent variable scores which loading values ranged between 0.5-0.6 with the number of indicators ranged from 3-7 (Ghazali, 2015). Tests were also carried out based on the Average Variance Extracted (AVE) value with latent variable under good criteria if AVE score $\geq 0.5$.

Table 1 - The Results of Validity Test that Matched the Criteria

\begin{tabular}{|c|c|c|c|c|}
\hline $\mathrm{n} / \mathrm{n}$ & Loading Factor & T-Statistic & AVE & Conclusion \\
\hline Business Innovation $(\mathrm{X})$ & & & 0.682 & Valid \\
\hline $\mathrm{X} 1{ }^{1}$ & 0.792 & 15.603 & & Valid \\
\hline $\mathrm{X} 1 .^{2}$ & 0.759 & 14.744 & & Valid \\
\hline $\mathrm{X} 1{ }^{3} 1{ }^{4}$ & 0.912 & 43.142 & & Valid \\
\hline Advantage (Y) & 0.832 & 29.344 & & Valid \\
\hline $\mathrm{Y} 1 .{ }^{2}$ & & & 0.717 & Valid \\
\hline $\mathrm{Y} 1{ }^{2}$ & 0.933 & 81.122 & & Valid \\
\hline $\mathrm{Y} 1{ }^{5}$ & 0.892 & 41.133 & & Valid \\
\hline
\end{tabular}

Source: SmartPLS Output, 2018.

Table 2 - The Results of Reliability Test on Latent Variables

\begin{tabular}{|c|c|c|c|}
\hline $\mathrm{n} / \mathrm{n}$ & Composite Reliability & Cronbach's Alpha & Conclusion \\
\hline Business Innovation & 0.895 & 0.844 & Reliable \\
\hline Competitive Advantage & 0.882 & 0.798 & Reliable \\
\hline
\end{tabular}

Source: SmartPLS Output, 2018.

Based on the results of the validity and reliability tests, the indicators or items of the latent variables have been regarded valid and reliable.

The calculation of the accuracy of the research model (Inner Model) or Goodness of fit model showed that business innovation variable give $60 \%$ contribution toward the competitive advantage of micro food industry players in Southeast Sulawesi. The remaining $40.0 \%$ is influenced by other variables that were not included in this research model. In this research, the Goodness of fit model was measured using the dependent R-Square variable dependent output with the same interpretation as the regression. The following table presents the R-Square value. 
Table 3 - R-Square Value

\begin{tabular}{|c|c|}
\hline $\mathrm{n} / \mathrm{n}$ & R-square \\
\hline Competitive Advantage & 0.600 \\
\hline
\end{tabular}

Source: SmartPLS Output, 2018.

The following figure presents the results of the PLS path structural using SmartPLS.

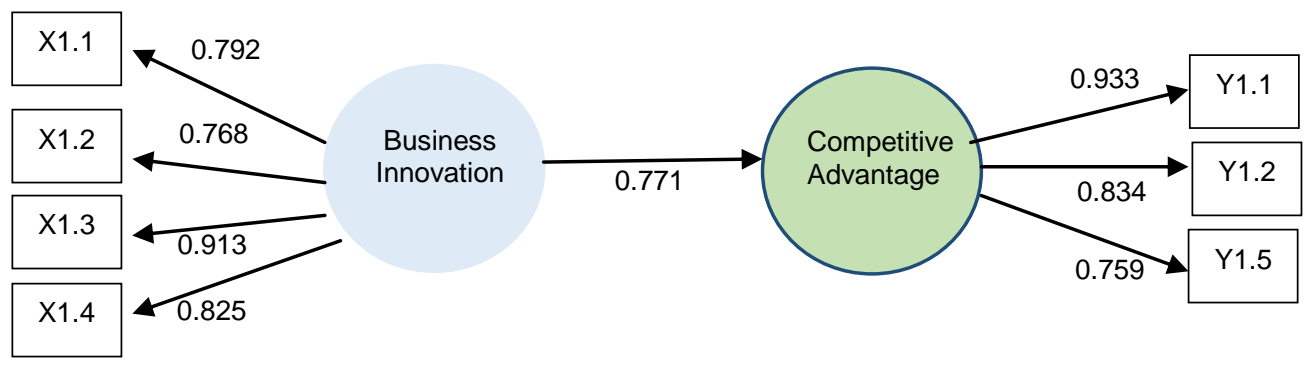

Figure 1 - SmartPLS Output

Meanwhile, the inner weight of the PLS structural path diagram is presented in the following table.

Table 4 - Result for Inner Weight

\begin{tabular}{|c|c|c|c|c|}
\hline $\mathrm{n} / \mathrm{n}$ & Original Sample Estimate & T-Statistic & T-Table & Conclusion \\
\hline Business Innovation $->$ Competitive Advantage & 0.771 & 20.899 & 1.96 & Significant \\
\hline
\end{tabular}

Source: Processed PLS.

The results of the statistical analysis showed that the influence of business innovation $(\mathrm{X})$ on competitive advantage $(\mathrm{Y})$ was 0.771 with a t-statistic value of 20.899 . The t-statistic value was greater than t-table 1.96 (t-statistic 20.899> t-table 1.96) with a significance level of $0.05(5 \%)$. Based on the results of these statistical calculations, it can be concluded that the latent variable, business innovation, has a significant positive effect on competitive advantage. Therefore, the proposed hypothesis can be accepted.

This research indicates that stronger attitude to continue to innovate in business will lead to the stronger value of the products offered by a company. Business innovation is more dominantly reflected by the importance of being able to bring marketing innovation supported organizational and management innovation, product innovation and production process innovation as well.

To bring good business innovation, food industry players in Southeast Sulawesi should create interesting and unique products with several variants. They should also make improvements in the company management and company organization.

Marketing innovations can be done in various ways. First, entrepreneurs must regard the relationship between objects, processes, materials, technology and people. To improve the creativity, we can refer to the natural environment. Creative people will have a certain intuitive relationship to recognize new relationships. In addition, to have creative and imaginative mind, we can use the right brain, while the left brain is used for work. Innovative creativity processes include logical and analytical thinking that include knowledge, evaluation and implementation. Hence, it is important to train and develop the abilities of the two brain hemispheres in order to improve creativity. Finally, to be creative and innovative in entrepreneurship, ones have to always think positively.

This kind of innovation demands the power of imagination in anticipating various situations. Innovative thinking is a process that brings solutions or ideas outside beyond the box (beyond conservative frame), both in terms of the knowledge of individuals or the dominant knowledge in an environment. Innovative thinking brings up new ideas that in the process must fulfill four fundamental aspects, namely: 1 . High sensitivity to various problems 
that could not be recognized by most people; 2 . High productivity which refers to the ability to produce as many answers as possible for one question; 3. High elasticity referring to the ability to produce varied thoughts; 4) High originality which refers to the ability to produce unique and new ideas than ever.

Brief look at the notion of innovation leads to a conclusion that innovation in an organization is a skill or ability of a company's resources to do and create new things both in a formal and informal context. Innovation that occurs in an organization is a process of organizational progress. However various obstacles might occur and should be anticipated when the innovation begins to be implemented by the organization. To anticipate this, company leaders need to understand the process of innovation in the organization that allow them to at least to reduce the turmoil of the organization in implementing the fusion of innovation.

Innovation can be defined as a certain "process" of a person through the utilization of thought, imagination ability, various stimulations and surrounding individuals to produce new products, both for themselves or for their environment.

There are several innovation requirements as outlined below. First, the new product must benefit the community in its environment. Second, the product is always relative that it can be something new for some people. The bias might be something new both some people as well. Within these conditions, the new product can be categorized as an innovation. Third, besides having a new nature, this product must also have functions and benefits that can address certain needs of individuals or groups of people (Jawwad, AA, 2004: 1).

Based on the results of this study, industry players are recommended to conduct business innovations, especially marketing innovations in order to have greater business competitive advantage. This way, a company will be able to improve its productivity and its market can be expanded, allowing a company to market its product in a broader scope. In the current digital era, digital marketing systems can also be utilized in conducting marketing innovation of MSME products.

Seen from the results of the statistical analysis conducted in this research, business innovation affects business competitive advantage by $60 \%$. This research can be further developed by including other variables such as government support and network cooperation system.

\section{CONCLUSION AND RECOMMENDATIONS}

Business innovation has been found to have significant and positive influence on the competitive advantage of the products produced by micro food industry in Southeast Sulawesi. Business innovation is an important aspect that should be concerned by business players. Business innovation includes marketing innovation, product innovation, and organizational innovation.

The findings of this research confirm that business innovation has a significant and positive influence on the competitive advantage of products produced by food industries in Southeast Sulawesi. Future researchers are encouraged to expand this research by adding more variables such as government support and network cooperation system. In addition, to improve the productivity of the food industry, the government is expected to give adequate support through relevant institutions to assist and give guidance to business players.

\section{REFERENCES}

1. Dinas Perindustrian and Perdagangan Provinsi Sulawesi Tenggara, 2016. Rekapitulasi Data Industri Mikro, Kecil and Menengah.

2. Dhewanto, W., Indradewa, R., Ulfah, N,W., Rahmawati, S. Yoshanti, G. \& zendry, G. (2015): Manajemen Inovasi untuk Usaha Kecil and Mikro. Bandung: Alfabeta.

3. Eisenbeis, A. and Boerner, S. (2013): A Double-edged Sword: Transformational Leadership and Individual Creativity. British Journal of Management, 24(1), pp. 54-68. 
4. Ghozali, I. 2006. Structural Equation Model: Metode Alternatif denganPArtial Least Square (PLS), Badan Penerbit UNDIP, Semarang.

5. Hadiyati, E. (2012), Kreativitas and Inovasi Pengaruhnya Terhadap Pemasaran Kewirausahaan Pada Usaha Kecil, Jurnal Inovai and Kewirausahaan, 1(3), 135-151.

6. Hartini, S. (2012). Peta Inovasi: Pengembangan Kualitas Produk and Kinerja Bisnis. Jurnal Manajemen and Kewirausahaan, 14(1), 82-88.

7. Kotler, Philip and Kevin Lane Keller, 2012, Marketing Management 13, New Jersey: Pearson Prentice Hall, Inc.

8. Najib, M, \& Kiminami, A (2011), Innovation, Cooperation and Business Performance: Some evidence from Indonesia Small Food Processing Cluster. Journal of Agribusiness in Develoving and Emerging economies, 1(1), 75-96

9. Rhee, Jaehoon, Taekyung Park and Do Hyung Lee, 2010. Divers od Innovativeness and Performance for Innovative SMEs in South Korea: Mediating od Learning Orientation. Journal Technovation. 30(1).pp.65-75.

10. Scarborough, N,M., \& Cornwall, J.R.,(2016). Essential of Entrepreneurship and Small Business Management, (Eighth Edition), London, Pearson.

11. Tjiptono, F. \& Chandra, G. 2012, Pemasaran Strategik. Yogyakarta: Andi.

12. Von Stamm, B. (2008) Managing Innovation, Design and Creativity. 2nd Edition, John Wiley \& Sons, Hoboken. 